\title{
Increased Carvone Production in Escherichia Coli by Balancing Expression of Limonene Conversion Enzymes Through Targeted QconCAT Proteome Analysis
}

Erika Yoshida ( $\nabla$ erika_yoshida@ajinomoto.com )

Ajinomoto Co., Inc. https://orcid.org/0000-0003-2201-8108

Motoki Kojima

KNC Laboratories Co., Ltd.

Munenori Suzuki

KNC Laboratories Co., Ltd.

Fumio Matsuda

Osaka University: Osaka Daigaku

Akiko Onuki

Ajinomoto Co., Inc.

Yousuke Nishio

Ajinomoto Co., Inc.

Yoshihiro Usuda

Ajinomoto Co., Inc.

Akihiko Kondo

Kobe University: Kobe Daigaku

Jun Ishii

Kobe University: Kobe Daigaku

Research

Keywords: Carvone, Proteomics, QconCAT, Bioconversion, Escherichia coli, Whole-cell biocatalysis

Posted Date: January 6th, 2021

DOI: https://doi.org/10.21203/rs.3.rs-139559/v1

License: (c) (i) This work is licensed under a Creative Commons Attribution 4.0 International License.

Read Full License 


\section{Abstract}

\section{Background}

Natural mint flavor is produced by extraction from mint, which is not efficient enough to make it environment friendly process. (-)-Carvone is the monoterpenoid with key flavor of spearmint, and there has been an attempt to produce (-)-carvone by recombinant Escherichia coli. Although all enzymes in (-)carvone biosynthesis have been functionally expressed in $E$. coli independently, the yield of (-)-carvone was low in the previous study.

Results

We have found a by-product formation when cytochrome P450 limonene-6-hydroxylase (P450)/cytochrome P450 reductase (CPR) and carveol dehydrogenase (CDH) were expressed in single cell. These by-products were determined as dihydrocarveol and dihydrocarvone. We hypothesized that the enzymatic kinetics and the expression levels of P450 and $\mathrm{CDH}$ are quite different in $E$. coli. Therefore, two strains independently expressing P450/CPR and CDH were mixed with different mixing ratio, confirming increase in carvone production and decrease in by-product formation when $\mathrm{CDH}$ input was reduced. To determine the optimum balance of enzyme expressions, proteome analysis quantification concatemer (QconCAT) method to quantify P450, CPR, and CDH was developed. Using the QconCAT standard protein that was artificially created by concatenating the tryptic peptides, the ratio between P450 and CDH was calculated, and their optimum ratio to maximize (-)-carvone production was shown. Then, a single strain expressing both $\mathrm{P} 450 / \mathrm{CPR}$ and $\mathrm{CDH}$ was constructed to imitate the superior expression ratio. The upgraded strain showed 15 -fold improvement compared to the initial strain, showing $44 \pm 6.3 \mathrm{mg} / \mathrm{L}$ of $(-)$-carvone production from $100 \mathrm{mg} / \mathrm{L}(-)$-limonene as a starting substrate.

\section{Conclusions}

Improved expression balance of $\mathrm{P} 450$ and $\mathrm{CDH}$ in recombinant $E$. coli increased the (-)-carvone production using (-)-limonene as the direct substrates by the whole-cell biocatalysis, showing approximately 150 times higher titer than previous report. Our study showed the usefulness of proteome analysis QconCAT method in the strain development for industrial biotechnology field.

\section{Background}

$(-)$-Carvone is a member of monoterpenoid and key flavor compound of spearmint essential oil [1]. (-)Carvone is utilized for spearmint flavor and fragrance in segments such as confectionery and oral care [2]. The annual production of (-)-carvone is approximately 3,800 tons per year, the majority of which (approximately 2,000 tons per year) is made by chemical synthesis from (+)-limonene [3]. Due to enhanced health- and environment-awareness in recent years, more consumers prefer natural flavors and fragrances for better perception [4]. Spearmint flavor is not an exception, so that the demand for natural spearmint flavor, or natural (-)-carvone is increasing. The spearmint essential oil is currently the only 
source of natural spearmint flavor, including natural (-)-carvone. There has been an issue that the demand for natural spearmint flavor exceeds the supply. To increase the supply is not simple, since current spearmint essential oil production method is water-intensive and requires improvement to be sustainable. Also, spearmint cultivation can be easily affected by the weather, such as drought, so that the spearmint essential oil supply volume and unit price is fluctuating [5]. Therefore, it is desirable to develop sustainable and stable natural (-)-carvone production method in order to accommodate the market demands.

One possible solution is (-)-carvone production by fermentation in a microbe. There are numerous attempts to produce flavor and fragrance compounds by biotechnology rather than extracting from its natural sources, because it has potential to be more sustainable and stable [6]. The regulatory circumstance is also supporting such attempts. For example, the flavor and fragrance compounds produced by biotechnology (regardless of the microbial or enzymatic process) can be labeled as "natural," according to European regulation CE 1334/2008 [7]. Therefore, (-)-carvone produced by biotechnology method can be labeled as natural (-)-carvone, and sustainably replace natural (-)-carvone conventionally produced by extracting from spearmint. To our knowledge, there is no natural (-)-carvone produced by biotechnology in the market yet.

The purpose of our study is to develop the sustainable and cost-effective replacement of carvone production by using microbes. (-)-Carvone is synthesized from the precursor (-)-limonene in its native producer spearmint. Specifically, intracellular (-)-limonene is converted to (-)-trans-carveol by cytochrome P450 limonene-6-hydroxylase (along with cytochrome P450 reductase; CPR), while (-)-trans-carveol is converted to (-)-carvone by carveol dehydrogenase (CDH) (Fig. 1). The enzymology of (-)-carvone biosynthesis in spearmint has been studied in detail $[8,9]$. The cytochrome P450 limonene-6-hydroxylase and $\mathrm{CDH}$ have been functionally expressed in Escherichia coli $[10,11]$. However, when these three genes were expressed in a single $E$. coli cell, a very low level of (-)-carvone (up to $2 \mu \mathrm{M}$ ) can be obtained from whole-cell biocatalysis with (-)-limonene supplementation [12]. The reason for the low conversion rate was still not clear, however, one general issue among heterologous expression of cytochrome P450 of plant origin is the difficulty to express in a heterologous host such as $E$. coli [13]. In order to increase the target compound production by plant origin cytochrome P450 in E. coli, careful fine-tuning at protein level to balance the expression of P450 along with other pathway enzymes was necessary [14]. Indeed, heterologous expression of cytochrome P450 limonene-6-hydroxylase required intensive N-terminal modification [10], whereas $\mathrm{CDH}$ was expressed well in soluble form without any modification [11]. Kinetic parameter information of these two enzymes were limited, but it appeared that P450 reaction was ratelimiting in spearmint plant [9]. Based on these prior studies, we hypothesized that the expression levels and the enzymatic kinetics of P450 and $\mathrm{CDH}$ are quite different, leading imbalance in the carvone biosynthesis pathway in E. coli, and ultimately causing the low conversion rate from (-)-limonene to (-)carvone. To investigate such hypothesis, it was desired to have a protein quantification method with high sensitivity to conduct comparative study among various strains by abundance ratio of pathway enzymes. 
Proteome analysis is a powerful tool for quantification of proteins. Proteome analysis can be divided into two types, relative quantification and absolute quantification. The relative quantification method in proteome analysis can be conducted without the laborious preparation of standard proteins; however, different proteins cannot be compared for expression level. The absolute quantification method requires a synthetic, isotope-labeled standard peptide (AQUA) preparation [15]. AQUA peptide preparation is still relatively expensive so that it is hardly performed in strain construction for industrial biotechnology fields. Another method for quantification standard preparation is by individually purify each target proteins in an isotope-labeled form, called the PSAQ method [16]. Alternatively, the quantification concatemer (QconCAT) method enables the standard peptide preparation easier and cheaper [17]. In the QconCAT method, targeted peptides are concatenated into a QconCAT protein, which is spiked in as a standard in proteome analysis. For our purpose, QconCAT method appears to be an attractive choice. There are a few studies that used the QconCAT method for quantification of proteins in prokaryote [18-20]; however, to our knowledge, there is no reports that the QconCAT method was applied to genetic engineering for upgrading metabolic pathways. In recent years, DNA synthesis became extremely accessible, so that the QconCAT method has a potential to become more popular among the synthetic biology field.

In this study, we developed a QconCAT method to quantify the expression of carvone biosynthetic pathway enzymes, P450, CPR and $\mathrm{CDH}$. Upon receiving our hypothesis of imbalanced P450 and CDH expression in E. coli, two strains independently expressing P450/CPR and CDH were mixed with different mixing ratio, and the QconCAT method was used to determine the optimum expression balance between the P450 and CDH. Based on this proteome analysis data, a single strain expressing both P450/CPR and $\mathrm{CDH}$ with superior expression ratio was constructed. This upgraded strain displayed 15 -fold improvement of (-)-carvone production compared to our initial strain, and achieved increase of (-)-carvone titer approximately 150 times higher than the previous report. To our knowledge, this is the first report in genetic engineering for upgrading metabolic pathways using the QconCAT method.

\section{Results}

\section{Cloning and functional expression of P450 genes in E. coli}

The cytochrome P450 (-)-(4S)-limonene-6-hydroxylase gene CYP71D18 of spearmint (Mentha spicata) was codon-optimized for E. coli, and cytochrome P450 reductase (CPR) gene ATR2 of Arabidopsis thaliana was used as the native sequence. These two genes were cloned into pCDFDuet-1 vector and were validated to be consistent with the designed sequences. E. coli BL21(DE3) transformants harboring pCDF-ATR2 (named as Ma strain) or pCDF-CYP71D18-ATR2 (named as Mpa strain) were induced with IPTG, and whole-cell P450 enzymatic activity was tested with supplementation of (-)-limonene as a substrate. E. coli strain Mpa, which is expressing both P450 and CPR demonstrated conversion of (-)limonene to (-)-trans-carveol (Fig. 2A). Whole cell activity was defined as final concentration of (-)-transcarveol per hour per $\mathrm{OD}_{600}\left(\mathrm{mg} \times \mathrm{L}^{-1} \mathrm{~h}^{-1} \mathrm{OD}_{600}{ }^{-1}\right)$. Mpa cells showed whole cell P450 activity of 2.4 $\left(\mathrm{mg} \times \mathrm{L}^{-1} \mathrm{~h}^{-1} \mathrm{OD}_{600}{ }^{-1}\right)$. 


\section{Cloning and functional expression of $\mathrm{CDH}$ genes in E. coli}

For carveol dehydrogenase (CDH), we have tested two genes, one from peppermint (Mentha x piperita) and another one from Rhodococcus erythropolis. First, CDH gene ISPD of peppermint was codonoptimized and cloned into pET-3a vector. The sequence was validated to be consistent with the designed sequence. E. coli BL21(DE3) transformant harboring PET-ISPD (named as Hc strain) was induced with IPTG, and whole-cell CDH enzymatic activity was tested with supplementation of (-)-carveol as a substrate (commercially available (-)-carveol contains (-)-trans-carveol and (-)-cis-carveol, and trace of $(-)$-carvone). E. coli strain Hc, which is expressing ISPD, demonstrated conversion of (-)-trans-carveol to (-)-carvone (Fig. 2B). The CDH activity of ISPD-expressing cells was specific towards (-)-trans-carveol and not to (-)-cis-carveol, which is consistent with a previous study [11]. Whole cell CDH activity was defined as final concentration (-)-carvone of per hour per $\mathrm{OD}_{600}\left(\mathrm{mg} \times \mathrm{L}^{-1} \mathrm{~h}^{-1} \mathrm{OD}_{600}{ }^{-1}\right)$. Hc cells showed whole cell CDH activity of $4.9\left(\mathrm{mg} \times \mathrm{L}^{-1} \mathrm{~h}^{-1} \mathrm{OD}_{600}{ }^{-1}\right)$.

In addition to $\mathrm{CDH}$ from peppermint (ISPD), another CDH gene limC from $R$. erythropolis DCL14 was also codon-optimized and cloned into $\mathrm{pET}-3 \mathrm{a}$ and expressed in $E$. coli. There was no previous report of heterologous expression of this gene. E. coli BL21(DE3) transformant harboring pET-limC was induced with IPTG at various conditions, and SDS-PAGE of the cell lysate revealed a strong band with the molecular mass of $30 \mathrm{kDa}$, which corresponds to the size of CDH from R. erythropolis DCL14 (Additional file 1. A). This result indicated that $\mathrm{CDH}$ gene $\lim C$ was successfully expressed in E. coli BL21(DE3). Next, $\mathrm{CDH}$ enzymatic activity of expressed LimC was tested with supplementation of (-)-carveol as a substrate. E. coli strain expressing lim $C$ gene demonstrated conversion of (-)-carveol to (-)-carvone only under the presence of artificial electron acceptor dichlorophenolindophenol (DCPIP), as described in the previous study [21] (Additional file 1. B). Additional supplementation of artificial electron acceptor is not desirable in industrial production; therefore, we have selected CDH gene ISPD from peppermint in the remaining study.

\section{Biocatalysis of (-)-carvone from (-)-limonene}

The cytochrome P450 limonene 6-hydroxylase gene CYP71D18 of spearmint (referred to as P450 thereafter), cytochrome P450 reductase gene ATR2 of $A$. thaliana (referred to as CPR thereafter) and carveol dehydrogenase gene ISPD of peppermint (referred to as $\mathrm{CDH}$ thereafter) were individually confirmed its functional expression in E. coli. As a next step, a strain co-expressing P450, CPR and CDH was constructed (BL21(DE3) pCDF-CYP71D18-ATR2-ISPD, named as Mpac strain) and incubated with $(-)$-limonene as a substrate at different two temperatures. As a result, (-)-carvone was detected along with undesired by-product formation (Fig. 3A). Out of two reaction temperature conditions tested, $14{ }^{\circ} \mathrm{C}$ condition showed higher production of (-)-carvone than $20^{\circ} \mathrm{C}$ condition. To identify the cause of these by-product formations, P450, CPR, and CDH co-expressing strain (Mpac) and P450 and CPR expressing strain (Mpa) were incubated with (-)-carveol as a substrate, and different pattern of by-product formation was observed (Fig. 3B). Specifically, Mpac strain expressing CDH generated compound \#5, while Mpa strain that did not express $\mathrm{CDH}$ generated compound \#6 with a small quantity of compound \#7 (Fig. 3B). 
Similarity search of mass spectrometry (MS) fragment pattern, and further analysis of conversion mixture and authentic compound suggested that these by-products were dihydrocarveol (\#5) and dihydrocarvone (\#6) (Fig. 3C). The minor peak, \#7, was dihydrocarvone isomer (Fig. 3C). In addition, when (-)-carveol and (-)-carvone was incubated with wild type E. coli BL21(DE3) strain, dihydrocarvone formation was also observed (Additional file 2). These results indicated that the exogenous enzyme peppermint $\mathrm{CDH}$ (ISPD) generated dihydrocarveol and the endogenous $E$. coli enzyme generated dihydrocarvone as by-products.

\section{Optimization of carvone biocatalysis by QconCAT proteome analysis}

Since $\mathrm{CDH}$ was shown to cause the by-product formation, optimization of the expression ratio between P450/CPR and CDH was attempted. This experiment was conducted under the hypothesis that excessive $\mathrm{CDH}$ in the reaction may cause undesired by-product formation since whole-cell $\mathrm{CDH}$ activity was higher than whole-cell P450 activity. Mpa strain (BL21(DE3) harboring pCDF-CYP71D18-ATR2) and Hc strain (BL21(DE3) harboring pET-ISPD) were separately cultured, induced with IPTG, and mixed the various ratio with substrate (-)-limonene. Results of $\mathrm{Mpa}$ and $\mathrm{Hc}$ strains mixed at 100:100, 100:10, 100:1 ratio respectively, based on the OD value, were shown in Fig. 4. When P450/CPR and CDH expressing strains were mixed at 100:1 ratio, the (-)-carvone concentration reached to the maximum, while dihydrocarvone peak was minimum. To corroborate the hypothesis, BL21(DE3) transformant harboring the high-copy $\mathrm{CDH}$ expression plasmid (pET-ISPD) along with pCDF-CYP71D18-ATR2 was generated (MpaHc strain) and confirmed that MpaHc presumably with high $\mathrm{CDH}$ expression drastically decreased the carvone production (Table 3).

Next, we aimed to determine the optimum ratio between P450/CPR and CDH at the protein level. One issue for such a strategy was that there was no method to quantify protein, especially P450.

Heterologous expression of CYP71D18 was not detectable by SDS-PAGE analysis, while other proteins, $\mathrm{CPR}$ and $\mathrm{CDH}$ were readably detectable (data not shown). As data in Fig. 4 clearly showed that reducing $\mathrm{CDH}$ amount in the reaction is beneficial to increase (-)-carvone conversion, it is necessary to have the quantitative result of protein expression level to determine the optimum abundance ratio among pathway enzymes, so that the optimum ratio can be represented in the optimized strain. Therefore, the semiquantitative proteome analysis method using quantification concatemer (QconCAT) protein was developed for P450, CPR, and CDH quantification.

In this method, we firstly determined the candidate peptides to be analyzed, based on the amino acid sequence of P450, CPR, and CDH. Next, we analyzed actual samples from strains expressing these proteins and selected two peptides for each protein by its detection strength. Then, artificial standard QconCAT proteins were constructed. In QconCAT protein design, each peptide to be analyzed in LCMS/MS were concatenated next to each other. Two different designs by arranging different order were attempted, namely QconCAT1 and QconCAT2 (Fig. 5A). The DNA sequences corresponding to these artificial proteins were synthesized and inserted to pET-28a vector. E. coli BL21(DE3) transformants 
harboring pET28a-QconCAT1 or pET28a-QconCAT2 were induced with IPTG, and SDS-PAGE of the cell lysate revealed a band with a molecular mass of $20 \mathrm{kDa}$, which corresponds to QconCAT protein as designed. Both were His-tag purified to single band purity (Fig. 5B).

These QconCAT proteins were treated with trypsin, and the detection of all peptide included in the design was confirmed in advance. We determined to use the QconCAT1 protein, of which the yield after purification was higher than the QconCAT2 (Fig. 5B), for further experiments. Then, the strain expressing QconCAT1 protein was cultured in the labeled medium where all glucose was substituted with $\left[\mathrm{U}^{13} \mathrm{C}_{6}\right]$ glucose, induced with IPTG, then purified as previously. This labeled purified QconCAT1 protein was used as a standard for proteome analysis. The proteome analysis was conducted with strains expressing P450, CPR, and CDH (MpaHc), P450 and CPR (Mpa) or CDH (Hc), and relative expression amount versus QconCAT1 was determined (Fig. 5C). It was clearly shown that in MpaHc strain, P450 expression was very low, whereas both $\mathrm{CPR}$ and $\mathrm{CDH}$ expressions were high.

Using the QconCAT proteome analysis result, the $\mathrm{P} 450 / \mathrm{CDH}$ ratio corresponding to Mpa and Hc mixture (100:100, 100:10, 100:1 ratio respectfully, based on the OD value) and MpaHc was calculated, and its correlation between carvone production was shown (Fig. 6). In the tested condition, (-)-carvone concentration reached the maximum when the $\mathrm{P} 450 / \mathrm{CDH}$ ratio was high as $16(\mathrm{Mpa}: \mathrm{Hc}=100: 1)$.

\section{Carvone conversion by single cell reaction}

Based on the result of the QconCAT proteome analysis, the additional strain was constructed in order to represent improved balance of P450 and CDH expression in single cell. Since the $\mathrm{CDH}$ gene was previously expressed from a high copy vector (pET-3a), low copy vector pMW218 was selected as a new vector backbone to express $\mathrm{CDH}$ at decreased expression level. Constructed plasmid pMW-ISPD was introduced into the $E$. coli BL21(DE3) strain with P450 expression plasmid pCDF-CYP71D18-ATR2-ISPD (MpaLc). The novel strain MpaLc along with previously constructed strains with pET-ISPD (MpaHc) were analyzed using QconCAT proteome analysis and carvone biocatalysis assay. MpaLc produced $44 \pm$ $6.3 \mathrm{mg} / \mathrm{L}$ of (-)-carvone from $100 \mathrm{mg} / \mathrm{L}(-)$-limonene as a starting substrate, whereas MpaHc produced $2.9 \pm 0.79 \mathrm{mg} / \mathrm{L}$ of (-)-carvone (Fig. 7). The ratio P450/CDH of MpaLc was $12 \pm 1.5$, whereas MpaHc was $0.004 \pm 0.0008$. The ratio $\mathrm{P} 450 / \mathrm{CDH}$ was higher in MpaLc as designed, and carvone biocatalysis was increased as aimed.

\section{Discussion}

Proteome data is becoming more important and popular in metabolic engineering [22]. In our study, we have successfully demonstrated the benefit of targeted QconCAT proteome analysis in genetic engineering for upgrading metabolic pathways. The QconCAT method enables semi-quantitative analysis so that the abundance ratio between pathway enzymes can be determined. Such information is powerful when the imbalance of enzyme expression is a bottleneck in production strain. The relative quantification method in proteome analysis only allows comparison among the same protein in different strains, where 
the semi-quantitative method in proteome analysis allows comparison among different proteins in different strains. In (-)-limonene production pathway, it was necessary to balance the expression level between P450 and $\mathrm{CDH}$, since excessive $\mathrm{CDH}$ was shown to cause by-product formation. In order to investigate the optimum conversion condition, two strains independently expressing P450/CPR and CDH were mixed with different mixing ratio, then the QconCAT method revealed the optimum abundance ratio between P450/CPR and CDH.

Using this proteome data, upgraded strain was constructed to represent the optimum abundance ratio between the P450/CPR and CDH within a single cell. This upgraded strain displayed 15 -fold improvement of (-)-carvone production compared to our initial strain and achieved increase of (-)-carvone titer approximately 150 times higher than the previous report [12]. To our knowledge, this is the first report in genetic engineering for upgrading metabolic pathways using the QconCAT method. Imbalance of pathway enzyme expression is a very common issue in genetic engineering, and we believe that semiquantitative proteome analysis would provide clear answer in strain development strategy. The QconCAT method requires the preparation of labeled and purified QconCAT protein, but once it is prepared multiple rounds of the experiment can be performed. The downside of QconCAT is that the target protein to be measured cannot be changed after QconCAT preparation. It is required to decide the pathway design before constructing the QconCAT protein. Therefore, the QconCAT method is most effective at the later phase of the strain construction when the fine-tuning of pathway enzyme expression balance is required, rather than the earlier phase of the strain construction when pathway enzyme selection is being performed. The methodology we have developed can be applied in a wide variety of target compound in synthetic biology.

Our study shows for the first time, to our knowledge, that (-)-carvone biocatalysis from (-)-limonene in engineered $E$. coli can lead to the undesired by-product formation. Dihydrocarveol was detected when (-)carveol was incubated with cells expressing $\mathrm{CDH}$. Dihydrocarvone was detected when (-)-carveol was incubated with cells not expressing $\mathrm{CDH}$. Dihydrocarvone was also produced when (-)-carvone was incubated with $E$. coli wild type strain. Based on these results, we propose a hypothetical by-product formation pathway (Fig. 8). ISPD, the CDH from peppermint, is reported to be active to the substrates such as (-)-trans-carveol, (-)-trans-isopiperitenol, (+)-neomenthol, and (+)-neoisomenthol [11]. ISPD is reported to be not active to substrates such as (-)-cis-carveol, (-)-menthol, (+)-isomenthol, and (-)-perillyl alcohol [11]. ISPD was unable to catalyze the reduction of (-)-isopiperitenone, nor (-)-carvone [11]. There was no data regarding ISPD's activity to dihydrocarveol or dihydrocarvone. The essential oil of spearmint is consists of carvone (51.7\%), dihydrocarveol (11.5\%), and cis-dihydrocarvone (9.1\%) [1]. However, the enzyme which is responsible for the formation of dihydrocarveol and dihydrocarvone in spearmint is unknown. To elucidate this pathway, in vitro assay of ISPD is desired in future work. For the industrial purposes, it is strongly desired to reduce by-product formation so the overall production cost can be minimized. The $E$. coli endogenous gene which is responsible for the reaction from (-)-carvone to dihydrocarvone is also unknown. It is possible to search for the gene by screening, however, there could be multiple genes responsible for such reaction so that it requires multiple gene deletions. We took a rather realistic approach to overcome this situation, by reducing the $\mathrm{CDH}$ expression level to balance 
against P450 and optimizing reaction condition to prevent further production of the by-products. In our final strain (MpaLc), dihydrocarveol and dihydrocarvone were still present. To reduce these by-products, further optimization is necessary.

The purpose of this study was to develop the production method of natural (-)-carvone by biotechnology. We have shown that $E$. coli whole cell bioconversion method from (-)-limonene as a feeding substrate. $(-)$-Limonene is a highly volatile compound and solubility to water is low. The uptake of the substrate can be the limitation of this reaction as prior study suggests [12]. Therefore, our next target is to integrate the developed pathway of carvone conversion with limonene biosynthesis pathway. Limonene producer strain has been reported in several literature $[23,24]$. We aim to construct limonene high producer strain then introduce carvone conversion pathway. We can take an approach to produce carvone by direct fermentation from substrates such as simple sugar. By doing so, intracellular limonene can be efficiently converted into carveol and carvone accordingly. Direct fermentation method with high titer and productivity can reduce production cost, and potentially becoming environment-friendly and costeffective method of natural mint flavor production in near future.

\section{Conclusions}

The (-)-carvone biosynthesis pathway genes, cytochrome P450 limonene-6-hydroxylase, cytochrome $\mathrm{P} 450$ reductase, and carveol dehydrogenase from plants were introduced into $E$. coli to construct the whole-cell biocatalytic system. The whole-cell biocatalysis from (-)-limonene to (-)-carvone was attempted, and by-products such as dihydrocarveol and dihydrocarvone were detected in the reaction mixture. Best protein expression balance was determined using proteome analysis QconCAT method and resulted in strain representing the superior balance between cytochrome P450 limonene-6-hydroxylase and carveol dehydrogenase showed 15 -fold improvement compared to the strain before engineering. Upgraded strain (MpaLc) produced $44 \pm 6.3 \mathrm{mg} / \mathrm{L}$ of (-)-carvone from $100 \mathrm{mg} / \mathrm{L}(-)$-limonene as a starting substrate, where control strain (MpaHc) produced $2.9 \pm 0.79 \mathrm{mg} / \mathrm{L}$ of $(-)$-carvone and attained 150 times higher production titer than the previous report. Our study showed the usefulness of the proteome analysis QconCAT method in the industrial biotechnology field.

\section{Methods}

\section{Plasmid construction}

Plasmids used in this study were listed in Table 1. Codon-optimization of CYP71D18 gene was done for E. coli using the GeneArt Strings ${ }^{\text {TM }}$ DNA Fragments service by Life Technologies Corporation (Carlsbad, CA, USA). Codon-optimization of the remaining genes except for ATR2 gene was done for $E$. coli using the OptimumGene algorithm by GenScript Biotech Corporation (Piscataway, NJ, USA). Detailed sequences are shown in additional file 3. Cytochrome P450 reductase (ATR2, Accession number NM_119167) gene derived from Arabidopsis thaliana was truncated by 72 amino acids to remove hypothetical membrane anchoring region and then tag sequence for soluble expression was added and inserted at multiple 
cloning site 2 (MCS2) of pCDFDuet-1 vector to construct pCDF-ATR2 plasmid. Then, cytochrome P450 (CYP71D18, Accession number AF124815) gene derived from Mentha spicata was codon optimized for $E$. coli expression and truncated by 5 amino acids to remove hypothetical membrane anchoring region then tag sequence for soluble expression was added and inserted at multiple cloning site 1 (MCS1) of pCDFATR2 vector to construct pCDF-CYP71D18-ATR2. Carveol dehydrogenase (ISPD, Accession number AY641428) gene from Mentha x piperita was codon optimized for $E$. coli expression and inserted at Sall site (in between P450 and ATR2 genes) of pCDF-CYP71D18-ATR2 plasmid with SD sequence to construct pCDF-CYP71D18-ATR2-ISPD plasmid. ISPD gene was also inserted at Ndel-BamHI site of pET-3a plasmid to construct pET-ISPD plasmid. Similarly, ISPD was inserted at Kpnl-Sall site of pMW218 to construct pMW-ISPD. Carveol dehydrogenase (IimC, Accession number AJ006869) gene from Rhodococcus erythropolis DCL14 was codon optimized for E. coli expression and inserted at Ndel-BamHI site of pET-3a plasmid to construct pET-limC plasmid. QconCAT1 gene (design detail is described in QconCAT standard protein preparation) was codon optimized for E. coli expression and inserted at BamHI-Xhol site of pET28a plasmid to construct pET-QconCAT1 plasmid. QconCAT2 gene (design detail is described in QconCAT standard protein preparation) was codon optimized for $E$. coli expression and inserted at BamHI-Xhol site of pET-28a plasmid to construct pET-QconCAT2 plasmid. 
Plasmids used in this study

\begin{tabular}{|c|c|c|}
\hline $\begin{array}{l}\text { Plasmid } \\
\text { name }\end{array}$ & Description & $\begin{array}{l}\text { Source } \\
\text { of } \\
\text { reference }\end{array}$ \\
\hline pCDFDuet- & $\begin{array}{l}\text { Expression vector carrying two multiple cloning sites with T7/ac promoter } \\
\text { and ribosome biding site, CloDF13-derived CDF replicon, lacl gene and } \\
\text { streptomycin/spectinomycin resistance gene. }\end{array}$ & Novagen \\
\hline pCDF-ATR2 & $\begin{array}{l}\text { Cytochrome P450 reductase (ATR2, Accession number NM_119167) gene } \\
\text { derived from Arabidopsis thaliana was inserted at multiple cloning site } 2 \\
\text { (MCS2) of pCDFDuet-1. }\end{array}$ & $\begin{array}{l}\text { This } \\
\text { study }\end{array}$ \\
\hline $\begin{array}{l}\text { pCDF- } \\
\text { CYP71D18- } \\
\text { ATR2 }\end{array}$ & $\begin{array}{l}\text { Cytochrome P450 (CYP71D18, Accession number AF124815) gene } \\
\text { derived from Mentha spicata was inserted at multiple cloning site } 1 \\
\text { (MCS1) of pCDF-ATR2. }\end{array}$ & $\begin{array}{l}\text { This } \\
\text { study }\end{array}$ \\
\hline $\begin{array}{l}\text { pCDF- } \\
\text { CYP71D18- } \\
\text { ATR2-ISPD }\end{array}$ & $\begin{array}{l}\text { Carveol dehydrogenase (ISPD, Accession number AY641428) gene from } \\
\text { Mentha x piperita was inserted at Sall site (in between P450 and CPR } \\
\text { genes) of pCDF-CYP71D18-ATR2 }\end{array}$ & $\begin{array}{l}\text { This } \\
\text { study }\end{array}$ \\
\hline pET-3a & $\begin{array}{l}\text { Expression vector carrying one cloning site with T7 promoter and } \\
\text { ribosome biding site, pBR322 replicon, and ampicillin resistance gene. }\end{array}$ & Novagen \\
\hline pET-ISPD & $\begin{array}{l}\text { Carveol dehydrogenase (ISPD, Accession number AY } 641428 \text { ) gene from } \\
\text { Mentha x piperita was inserted at Ndel-BamHI site of } \mathrm{pET}-3 \mathrm{a} \text {. }\end{array}$ & $\begin{array}{l}\text { This } \\
\text { study }\end{array}$ \\
\hline pMW218 & $\begin{array}{l}\text { Cloning vector carrying one multiple cloning site, pSC101 replicon, and } \\
\text { kanamycin resistance gene. }\end{array}$ & $\begin{array}{l}\text { Nippon } \\
\text { Gene }\end{array}$ \\
\hline pMW-ISPD & $\begin{array}{l}\text { Carveol dehydrogenase (ISPD, Accession number AY641428) gene from } \\
\text { Mentha x piperita was inserted at Kpnl-Sall site of pMW218. }\end{array}$ & $\begin{array}{l}\text { This } \\
\text { study }\end{array}$ \\
\hline pET-limC & $\begin{array}{l}\text { Carveol dehydrogenase ( } \lim C \text {, Accession number AJ006869) gene from } \\
\text { Rhodococcus erythropolis DCL } 14 \text { was inserted at Ndel-BamHI site of pET- } \\
\text { 3a. }\end{array}$ & $\begin{array}{l}\text { This } \\
\text { study }\end{array}$ \\
\hline pET-28a & $\begin{array}{l}\text { Expression vector carrying one cloning site with T7/ac promoter and } \\
\text { ribosome biding site, N-terminal } \\
\text { His·Tag®/thrombin/T7·Tag® configuration, pBR322 replicon, and } \\
\text { kanamycin resistance gene. }\end{array}$ & Novagen \\
\hline $\begin{array}{l}\text { pET- } \\
\text { QconCAT1 }\end{array}$ & QconCAT1 sequence was inserted at BamHI-Xhol site of pET-28a. & $\begin{array}{l}\text { This } \\
\text { study }\end{array}$ \\
\hline $\begin{array}{l}\text { pET- } \\
\text { QconCAT2 }\end{array}$ & QconCAT2 sequence was inserted at BamHI-Xhol site of pET-28a. & $\begin{array}{l}\text { This } \\
\text { study }\end{array}$ \\
\hline
\end{tabular}

\section{Strains}

Strains used in this study were listed in Table 2. E. coli BL21(DE3) was used as the host strain for protein expression and biocatalysis. 
Table 2

Strains used in this study

\begin{tabular}{|c|c|c|}
\hline & \\
\hline Strain & Parental strain & Plasmid \\
\hline $\mathrm{Ma}$ & BL21(DE3) & pCDF-ATR2 \\
\hline Mpa & BL21(DE3) & pCDF-CYP71D18-ATR2 \\
\hline Mpac & BL21(DE3) & pCDF-CYP71D18-ATR2-ISPD \\
\hline $\mathrm{Hc}$ & BL21(DE3) & pET-ISPD \\
\hline $\mathrm{H}$ & BL21(DE3) & $\mathrm{pET}$ \\
\hline MpaHc & BL21(DE3) & pCDF-CYP71D18-ATR2, pET-ISPD \\
\hline Lc & BL21(DE3) & pMW-ISPD \\
\hline MpaLc & BL21(DE3) & pCDF-CYP71D18-ATR2, pMW-ISPD \\
\hline
\end{tabular}

The recombinant strain BL21(DE3) harboring expression plasmids were grown at $37^{\circ} \mathrm{C}$ in $\mathrm{LB}$ medium as the seed culture. The seed culture was inoculated into $20 \mathrm{~mL}$ of TB broth medium (Bacto tryptone $12 \mathrm{~g}$, Bacto yeast extract $24 \mathrm{~g}$, glycerol $4 \mathrm{~mL}, \mathrm{KH}_{2} \mathrm{PO}_{4} 2.31 \mathrm{~g}, \mathrm{~K}_{2} \mathrm{HPO}_{4} 12.54 \mathrm{~g}$ per 1 liter) at a ratio of $1 \%$ and incubated at $37^{\circ} \mathrm{C}$. In the case of P450 expression, $80 \mathrm{mg} / \mathrm{L}$ of 5 -amino levulinic acid and $100 \mu \mathrm{M}$ of $\mathrm{Fe}\left(\mathrm{NH}_{4}\right)\left(\mathrm{SO}_{4}\right)_{2}$ was added in the TB broth medium, to facilitate heme biosynthesis [25]. The antibiotic spectinomycin $(100 \mathrm{mg} / \mathrm{L})$, carbenicillin $(100 \mathrm{mg} / \mathrm{L})$, and kanamycin $(50 \mathrm{mg} / \mathrm{L})$ were used to maintain plasmid. When the optical density of the culture at $600 \mathrm{~nm}$ reached 0.8 , IPTG was added at a final concentration of $50 \mu \mathrm{M}$ and incubated at $20^{\circ} \mathrm{C}$ for 16 hours.

After induction, the cells were harvested by centrifugation and resuspended in $50 \mathrm{mM}$ of potassium phosphate buffer $(\mathrm{pH} 7.2)$ containing $5 \%(\mathrm{v} / \mathrm{v})$ glycerol. The cell suspension was diluted to make $\mathrm{OD}_{600}=$ 20 in final concentration, mixed with the substrate, and the biocatalysis reactions were performed at $14{ }^{\circ} \mathrm{C}$ for 16 hours or otherwise indicated. The reaction was carried out in GC vial or headspace vial with tightly closed lids. At substrate addition, vial and its contents were cooled by ice to reduce the volatilization of the substrate, especially (-)-limonene.

\section{Analytical method}

After the conversion reaction, vials were cooled by ice, then ethyl-acetate extraction was conducted. E. coli BL21(DE3) cells with a plasmid containing no insert were included as a negative control in these experiments. Obtained extracts were analyzed by gas chromatography (GC). GC-FID analysis was performed on a GC-2010Plus gas chromatograph (Shimadzu, Kyoto, Japan) equipped with a flame ionization detector (at $300^{\circ} \mathrm{C}$ ) and DB-1 column ( $30 \mathrm{~m}$ length, $0.25 \mathrm{~mm}$ internal diameter, $0.25 \mu \mathrm{m}$ film thickness, Agilent Technologies, Santa Clara, CA, USA). The analysis was carried out with a temperature program of initial temperature $65^{\circ} \mathrm{C}$ for $5 \mathrm{~min}, 5^{\circ} \mathrm{C} / \mathrm{min}$ to $145^{\circ} \mathrm{C}, 25^{\circ} \mathrm{C} / \mathrm{min}$ to $250^{\circ} \mathrm{C}$, then hold at 
$300{ }^{\circ} \mathrm{C}$ for $3 \mathrm{~min}$. The carrier gas was helium $(120.7 \mathrm{kPa}, 19.6 \mathrm{~mL} / \mathrm{min})$. Injection condition was split flow $1: 10,250^{\circ} \mathrm{C}$, linear velocity $35.0 \mathrm{~cm} /$ second.

GC mass spectrometry (GC-MS) analysis was performed on a GCMS-QP2010 system (Shimadzu) using an Rt- $\beta D E X$ column ( $30 \mathrm{~m}$ length, $0.25 \mathrm{~mm}$ internal diameter, $0.25 \mu \mathrm{m}$ film thickness, RESTEK, Bellefonte, $\mathrm{PA}, \mathrm{USA})$. The analysis was carried out with a temperature program of initial temperature $50{ }^{\circ} \mathrm{C}$ for $5 \mathrm{~min}$, $5^{\circ} \mathrm{C} / \mathrm{min}$ to $230^{\circ} \mathrm{C}$. The carrier gas was helium $(0.7 \mathrm{~mL} / \mathrm{min})$. Injection condition was split flow 1:10, $220^{\circ} \mathrm{C}$, linear velocity $30.4 \mathrm{~cm} /$ second. The interface temperature was $220^{\circ} \mathrm{C}$. The detector worked in the scan mode and detection was performed in the range of $\mathrm{m} / \mathrm{z} 40-400$.

\section{QconCAT standard protein preparation}

Two tryptic peptides were chosen based on the preliminary study to represent each protein. The peptide sequences were concatenated in two different orders to make QconCAT1 and QconCAT2 (Fig. 5A). This artificial gene was synthesized and cloned into BamHI-Xhol site of the PET-28a expression vector by GenScript Biotech Corporation (Pis-cataway, NJ, USA). Internal BamHI and Xhol sites were removed by substitution with a synonymous codon (Additional file 3). Resulting QconCAT expression plasmids were transformed to $E$. coli BL21(DE3) and maintained in LB medium containing kanamycin ( $50 \mathrm{mg} / \mathrm{L})$. A single colony was inoculated to $2 \mathrm{~mL}$ of the ${ }^{13} \mathrm{C}-\mathrm{M} 9$ medium $\left(\mathrm{Na}_{2} \mathrm{HPO}_{4} 6.78 \mathrm{~g}, \mathrm{KH}_{2} \mathrm{PO}_{4} 3 \mathrm{~g}, \mathrm{NH}_{4} \mathrm{Cl} 1 \mathrm{~g}\right.$, $\mathrm{NaCl} 0.5 \mathrm{~g}, \mathrm{MgSO}_{4} 0.24 \mathrm{~g}, \mathrm{CaCl}_{2} 11 \mathrm{mg}$, thiamine $10 \mathrm{mg}$, and [U- ${ }^{13} \mathrm{C}_{6}$ ] glucose $10 \mathrm{~g}$ per 1 liter) and incubated overnight at $37^{\circ} \mathrm{C}$. This seed culture was inoculated into $40 \mathrm{~mL}$ of the ${ }^{13} \mathrm{C}-\mathrm{M} 9$ medium at a ratio of $1 \%$ and incubated at $37^{\circ} \mathrm{C}$. When the optical density of the culture at $600 \mathrm{~nm}$ reached 0.6, IPTG was added at a final concentration of $1 \mathrm{mM}$ and incubated at $30{ }^{\circ} \mathrm{C}$ for 46 hours. Cells were harvested by centrifugation and resuspended in $10 \mathrm{~mL}$ of xTractor buffer (Clontech Laboratories, Inc., Mountain View, CA, USA) and the crude lysate was obtained according to the manufacturer's protocol for extracting proteins from bacterial cell culture. The lysate was His-tag purified using Capturem ${ }^{\mathrm{TM}}$ Maxiprep Kit (Clontech Laboratories, Inc.) according to the manufacturer's protocol. Purified protein concentration was measured by the Bradford method. Sample purity was confirmed by SDS-PAGE.

\section{Proteome analysis}

Total proteins were extracted as described previously with minor modification as following [26]. E. coli cells were harvested by centrifugation such that the $\mathrm{OD}_{600} \times$ volume $(\mathrm{mL})=50$, washed with $\mathrm{M} 9$ medium once, and then frozen at $-80^{\circ} \mathrm{C}$ until analysis. Cell pellets were resuspended in $1 \mathrm{~mL}$ lysis buffer $(50 \mathrm{mM}$ HEPES at pH 7.5, 5\% (v/v) glycerol, $15 \mathrm{mM}$ dithiothreitol, $100 \mathrm{mM} \mathrm{KCl}$, and $5 \mathrm{mM}$ EDTA). Resuspended cells were disrupted using a multi-beads shocker (Yasui Kikai Corporation, Osaka, Japan) with glass beads YGB01 (diameter $0.1 \mathrm{~mm}$, Yasui Kikai Corporation) at 10 cycles of $2500 \mathrm{rpm}$ for 30 seconds with a 30 seconds interval, and then centrifuged to collect the supernatant. The supernatants were used for protein quantitation using the Bradford method.

Next, $50 \mu \mathrm{g}$ of total protein and $2 \mu \mathrm{g}$ of QconCAT protein was supplemented with denaturing buffer $(500 \mathrm{mM}$ Tris- $\mathrm{HCl}$ at $\mathrm{pH} 8.5,10 \mathrm{mM}$ EDTA, $7 \mathrm{M}$ Guanidine $\mathrm{HCl}$ ) to the total volume of $220 \mu \mathrm{L}$. One 
microliter of $50 \mathrm{mg} / \mathrm{mL}$ dithiothreitol was added and mixed by vortexing at room temperature for $1 \mathrm{~h}$. Then, proteins were alkylated with $2.5 \mathrm{~mL}$ of $50 \mathrm{mg} / \mathrm{mL}$ iodoacetamide (IAA) with vortex mixing in the dark at room temperature for $1 \mathrm{~h}$. Six hundred microliters of ice-cold methanol, $150 \mu \mathrm{L}$ of chloroform, and $450 \mu \mathrm{L}$ of cold water were consecutively added to the lysates and mixed gently after the addition of each component. After centrifugation at $20,000 \times \mathrm{g}$ for $5 \mathrm{~min}$ at $4{ }^{\circ} \mathrm{C}$, the upper phase was discarded.

Subsequently, $450 \mu \mathrm{L}$ of methanol was added to the bottom phase as well as the interphase, and proteins were precipitated by centrifugation under the same conditions. Trypsin/LysC digestion was performed as described previously [27]. Proteins were dissolved in $9 \mu \mathrm{L}$ of $6 \mathrm{M}$ urea for $10 \mathrm{~min}$ by vortex mixing. Then, $36 \mu \mathrm{L}$ of $0.1 \mathrm{M}$ Tris $-\mathrm{HCl}(\mathrm{pH} 8.5)$ was added to the protein solution and mixed via sonication. Proteolytic digestion into peptides was performed using $1 \mu \mathrm{L}$ of $0.5 \mathrm{mg} / \mathrm{mL}$ lysyl endopeptidase (Lys-C; Wako Pure Chemical Industries, Osaka, Japan) at a final concentration of 1\% (w/w) Lys-C per sample protein and 2.5 $\mu \mathrm{L}$ of $1 \% \mathrm{w} / \mathrm{v}$ ProteaseMax Surfactant Trypsin Enhancer (Promega, Madison, WI, USA) at $25^{\circ} \mathrm{C}$ for $3 \mathrm{~h}$, followed by $1 \mu \mathrm{L}$ of $0.5 \mathrm{mg} / \mathrm{mL} \mathrm{L}$-1-tosylamide-2-phenylethyl chloromethyl ketone (TPCK)-trypsin (Promega) at a final concentration of $1 \%(\mathrm{w} / \mathrm{w})$ trypsin per sample protein at $37^{\circ} \mathrm{C}$ for $16 \mathrm{~h}$. Following trypsin digestion, $7.5 \mu \mathrm{L}$ water and $3 \mathrm{~mL}$ of $50 \%(\mathrm{v} / \mathrm{v})$ formic acid were added to the protein sample, which was then centrifuged at $20,000 \times \mathrm{g}$ for 5 min. Finally, $12 \mu \mathrm{L}$ of the sample was mixed with $36 \mu \mathrm{L}$ of $5 \%$ formic acid, and the mixtures were desalted with C18-StageTips [28-30].

Samples were analyzed by nano-liquid chromatography mass spectrometry (nano-LC-MS/MS). The nanoLC-MS/MS system comprised an LC-20Adnano and an LCMS-8060 triple-quadrupole mass spectrometer with an electrospray ionization ion source (Shimadzu). Sample separation was done by nano-LC (LC20Adnano), and electrospray ionization was performed by LCMS-8060. All analytical methods used were performed as described previously [31-33]. The multiple reaction monitoring (MRM) method used to relatively quantify 5 proteins was created by the open software Skyline version 4.1 [34], and shown in additional file 4. Peptides were relatively quantified by the peak area ratio of the ${ }^{12} \mathrm{C}$ sample to the ${ }^{13} \mathrm{C}$ sample derived from QconCAT1 protein.

\section{Abbreviations}

AQUA, absolute quantification; $C A G R$, compound average growth rate; $\mathrm{CDH}$, carveol dehydrogenase; $\mathrm{CPR}$, cytochrome P450 reductase; EDTA, ethylenediaminetetraacetic acid; DCPIP, dichlorophenolindophenol; FID, flame ionization detector; GC, gas chromatography; GC-MS, gas chromatography mass spectrometry; HEPES, 4-(2-hydroxyethyl)-1-piperazineethanesulfonic acid; IAA, iodoacetamide; IPTG, isopropyl $\beta$-D-1thiogalactopyranoside; ISPD, carveol dehydrogenase from peppermint; MCS, multiple cloning site; MRM, multiple reaction monitoring; MS, mass spectrometry; OD, optical density; PSAQ, protein standard absolute quantification; QconCAT, quantification concatemer; SDS-PAGE. sodium dodecyl sulfate polyacrylamide gel electrophoresis.

\section{Declarations}


This article does not contain any studies with human participants or animals performed by any of the authors.

\section{Consent for publication}

The authors provide consent for publication.

\section{Availability of data and materials}

The data supporting the conclusions of this article are included with the article. Strains examined are available from the corresponding author.

\section{Competing interests}

The authors declare no competing interests.

\section{Funding}

This work was supported by project P16009, Development of Production Techniques for Highly Functional Biomaterials Using Smart Cells of Plants and Other Organisms (Smart Cell Project), from the New Energy and Industrial Technology Development Organization (NEDO), Japan.

\section{Authors' contribution}

Conceived and designed the experiments: MS and YN. Performed the experiments: EY, MK, and MS. Performed the proteome analysis: FM. Wrote the paper: EY. Edited the paper: MK, MS, FM, AO, YN, YU, and JI. Project administration: MS, AO, and YN. Supervised the whole work: AO, YN, YU, and JI. Funding acquisition: AK. All authors read and approved the final manuscript.

\section{Acknowledgements}

We would like to thank Aya Komori (KNC Laboratories Co., Ltd) for plasmid construction and helpful discussions. We would like to thank Xiao Jing Li (WDB Co., Ltd.), Sayaka Kato (WDB Co., Ltd.) and Hiroshi Kitano (Osaka University) for help in experiment. We acknowledge Seizaburo Shiraga (Ajinomoto Co., Inc.) and Keiichi Yokoyama (Ajinomoto Co., Inc.) for support to this project. We would like to thank Yoshinori Tajima (Ajinomoto Co., Inc.) for discussion.

\section{References}

1. Buleandra M, Oprea E, Popa DE, David IG, Moldovan Z, Mihai I, et al. Comparative chemical analysis of Mentha piperita and M. spicata and a fast assessment of commercial peppermint teas. Nat Prod Commun. 2016;11:551-5.

2. De Carvalho CCCR, Da Fonseca MMR. Carvone: Why and how should one bother to produce this terpene. Food Chem. 2006;95:413-22. 
3. Lawrence BM. A Preliminary Report on the World Production of Some Selected Essential Oils and Countries. Perfum Flavor [Internet]. 2008 [cited 2020 Feb 12];38-9. Available from: https://www.cabdirect.org/cabdirect/abstract/20113147706

4. Krings U, Berger RG. Biotechnological production of flavours and fragrances. Appl Microbiol Biotechnol. 1998;49:1-8.

5. Grabenhofer RL. Mint: Market Growth, History, Sourcing, Formulation and Characterization. Perfurmer and Flavorist. 2016;

6. Jullesson D, David F, Pfleger B, Nielsen J. Impact of synthetic biology and metabolic engineering on industrial production of fine chemicals. Biotechnol Adv. 2015;33:1395-402.

7. Romero-Guido C, Belo I, Ta TMN, Cao-Hoang L, Alchihab M, Gomes N, et al. Biochemistry of lactone formation in yeast and fungi and its utilisation for the production of flavour and fragrance compounds. Appl Microbiol Biotechnol. 2011;89:535-47.

8. Karp F, Mihaliak CA, Harris JL, Croteau R. Monoterpene biosynthesis: Specificity of the hydroxylations of (-)-limonene by enzyme preparations from peppermint (Mentha piperita), spearmint (Mentha spicata), and perilla (Perilla frutescens) leaves. Arch Biochem Biophys. 1990;276:219-26.

9. Gershenzon J, Maffei M, Croteau R. Biochemical and Histochemical Localization of Monoterpene Biosynthesis in the Glandular Trichomes of Spearmint (Mentha spicata). Plant Physiol. 1989;89:1351-7.

10. Haudenschild C, Schalk M, Karp F, Croteau R. Functional expression of regiospecific cytochrome P450 limonene hydroxylases from mint (Mentha spp.) in Escherichia coli and saccharomyces cerevisiae. Arch Biochem Biophys [Internet]. 2000 [cited 2016 Aug 31];379:127-36. Available from: http://www.sciencedirect.com/science/article/pii/S0003986100918642

11. Ringer KL. Monoterpene Metabolism. Cloning, Expression, and Characterization of (-)Isopiperitenol/(-)-Carveol Dehydrogenase of Peppermint and Spearmint. Plant Physiol [Internet]. 2005;137:863-72. Available from: http://www.plantphysiol.org/cgi/doi/10.1104/pp.104.053298

12. Carter OA, Peters RJ, Croteau R. Monoterpene biosynthesis pathway construction in Escherichia coli. Phytochemistry. 2003;64:425-33.

13. Wei Y, Ang EL, Zhao H. Recent developments in the application of P450 based biocatalysts. Curr Opin Chem Biol [Internet]. Elsevier Ltd; 2018;43:1-7. Available from: http://dx.doi.org/10.1016/j.cbpa.2017.08.006

14. Biggs BW, Lim CG, Sagliani K, Shankar S, Stephanopoulos G, De Mey M, et al. Overcoming heterologous protein interdependency to optimize P450-mediated Taxol precursor synthesis in Escherichia coli. Proc Natl Acad Sci U S A. 2016;113:3209-14.

15. Gerber SA, Rush J, Stemman O, Kirschner MW, Gygi SP. Absolute quantification of proteins and phosphoproteins from cell lysates by tandem MS. Proc Natl Acad Sci U S A. 2003;100:6940-5.

16. Brun V, Dupuis A, Adrait A, Marcellin M, Thomas D, Court M, et al. Isotope-labeled protein standards: Toward absolute quantitative proteomics. Mol Cell Proteomics. 2007;6:2139-49. 
17. Beynon RJ, Doherty MK, Pratt JM, Gaskell SJ. Multiplexed absolute quantification in proteomics using artificial QCAT proteins of concatenated signature peptides. Nat Methods. 2005;2:587-9.

18. Al-Majdoub ZM, Carroll KM, Gaskell SJ, Barber J. Quantification of the proteins of the bacterial ribosome using QconCAT technology. J Proteome Res. 2014;13:1211-22.

19. Voges R, Corsten S, Wiechert W, Noack S. Absolute quantification of Corynebacterium glutamicum glycolytic and anaplerotic enzymes by QconCAT. J Proteomics [Internet]. Elsevier B.V.; 2015;113:36677. Available from: http://dx.doi.org/10.1016/j.jprot.2014.10.008

20. Batth TS, Singh P, Ramakrishnan VR, Sousa MML, Chan LJG, Tran HM, et al. A targeted proteomics toolkit for high-throughput absolute quantification of Escherichia coli proteins. Metab Eng [Internet]. Elsevier; 2014;26:48-56. Available from: http://dx.doi.org/10.1016/j.ymben.2014.08.004

21. Van Der Werf MJ, Boot AM. Metabolism of carveol and dihydrocarveol in Rhodococcus erythropolis DCL14. Microbiology. 2000;146:1129-41.

22. Alonso-gutierrez J, Kim E, Batth TS, Cho N, Hu Q, Jade L, et al. Principal component analysis of proteomics ( PCAP ) as a tool to direct metabolic engineering. Metab Eng [Internet]. Elsevier; 2015;28:123-33. Available from: http://dx.doi.org/10.1016/j.ymben.2014.11.011

23. Du F-L, Yu H-L, Xu J-H, Li C-X. Enhanced limonene production by optimizing the expression of limonene biosynthesis and MEP pathway genes in E. coli. Bioresour Bioprocess. 2014;1:10.

24. Alonso-Gutierrez J, Chan R, Batth TS, Adams PD, Keasling JD, Petzold CJ, et al. Metabolic engineering of Escherichia coli for limonene and perillyl alcohol production. Metab Eng [Internet]. Elsevier; 2013;19:33-41. Available from: http://dx.doi.org/10.1016/j.ymben.2013.05.004

25. Nakagawa A, Matsumura E, Koyanagi T, Katayama T, Kawano N, Yoshimatsu K, et al. Total biosynthesis of opiates by stepwise fermentation using engineered Escherichia coli. Nat Commun [Internet]. Nature Publishing Group; 2015;6:in press. Available from:

http://dx.doi.org/10.1038/ncomms10390

26. Toyoshima M, Sakata M, Ohnishi K, Tokumaru Y, Kato Y, Tokutsu R, et al. Targeted proteome analysis of microalgae under high-light conditions by optimized protein extraction of photosynthetic organisms. J Biosci Bioeng [Internet]. Elsevier Ltd; 2019;127:394-402. Available from: https://doi.org/10.1016/j.jbiosc.2018.09.001

27. Uchida Y, Tachikawa M, Obuchi W, Hoshi Y, Tomioka Y, Ohtsuki S, et al. A study protocol for quantitative targeted absolute proteomics (QTAP) by LC-MS/MS: application for inter-strain differences in protein expression levels of transporters, receptors, claudin-5, and marker proteins at the blood--brain barrier in ddY, FVB, an. Fluids Barriers CNS [Internet]. 2013;10:21. Available from: http://dx.doi.org/10.1186/2045-8118-10-

21\%5Cnhttp://www.fluidsbarrierscns.com/content/10/1/21/abstract

28. Rappsilber J, Mann M, Ishihama Y. Protocol for micro-purification, enrichment, pre-fractionation and storage of peptides for proteomics using StageTips. Nat Protoc. 2007;2:1896-906.

29. Ishihama Y, Rappsilber J, Mann M. Modular stop and go extraction tips with stacked disks for parallel and multidimensional peptide fractionation in proteomics. J Proteome Res. 2006;5:988-94. 
30. Rappsilber J, Ishihama Y, Mann M. Stop And Go Extraction tips for matrix-assisted laser desorption/ionization, nanoelectrospray, and LC/MS sample pretreatment in proteomics. Anal Chem. 2003;75:663-70.

31. Matsuda F, Ogura T, Tomita A, Hirano I, Shimizu H. Nano-scale liquid chromatography coupled to tandem mass spectrometry using the multiple reaction monitoring mode based quantitative platform for analyzing multiple enzymes associated with central metabolic pathways of Saccharomyces cerevisiae using ultra . J Biosci Bioeng [Internet]. Elsevier Ltd; 2015;119:117-20. Available from: http://dx.doi.org/10.1016/j.jbiosc.2014.06.010

32. Matsuda F, Kinoshita S, Nishino S, Tomita A, Shimizu H. Targeted proteome analysis of single-gene deletion strains of Saccharomyces cerevisiae lacking enzymes in the central carbon metabolism. PLoS One. 2017;12:1-20.

33. Matsuda F, Tomita A, Shimizu H. Prediction of Hopeless Peptides Unlikely to be Selected for Targeted Proteome Analysis. Mass Spectrom. 2017;6:A0056-A0056.

34. MacLean B, Tomazela DM, Shulman N, Chambers M, Finney GL, Frewen B, et al. Skyline: An open source document editor for creating and analyzing targeted proteomics experiments. Bioinformatics. 2010;26:966-8.

\section{Figures}

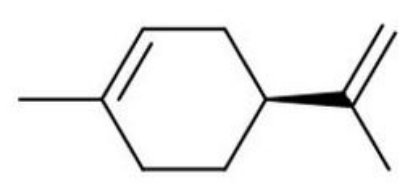

(-)-Limonene (1)

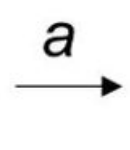

(-)-trans-Carveol (2)

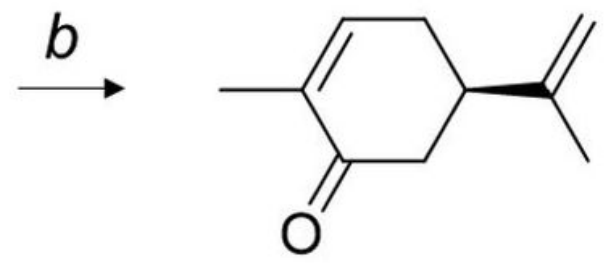

(-)-Carvone (3)

\section{Figure 1}

Biosynthesis pathway of carvone from limonene in Mentha sp. Pathway for the biosynthesis of (-)carvone from the primary precursor (-)-limonene is shown. The indicated enzymes are (a) cytochrome P450 limonene-6-hydroxylase, and (b) carveol dehydrogenase. 

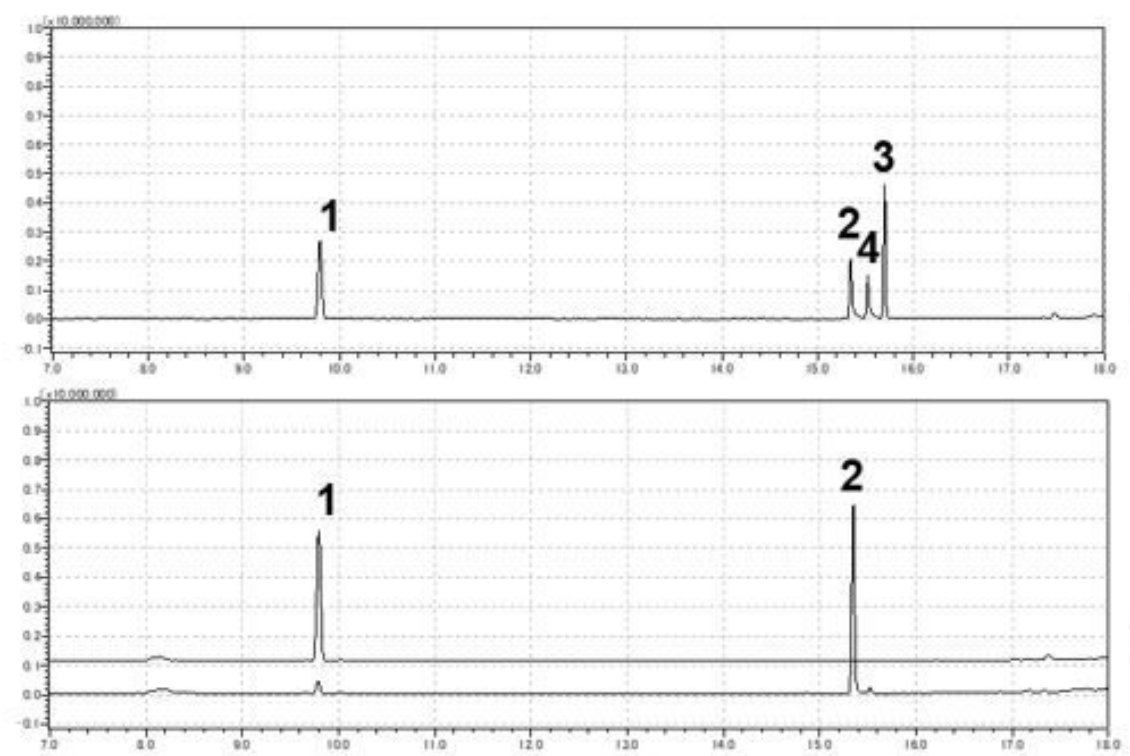

B
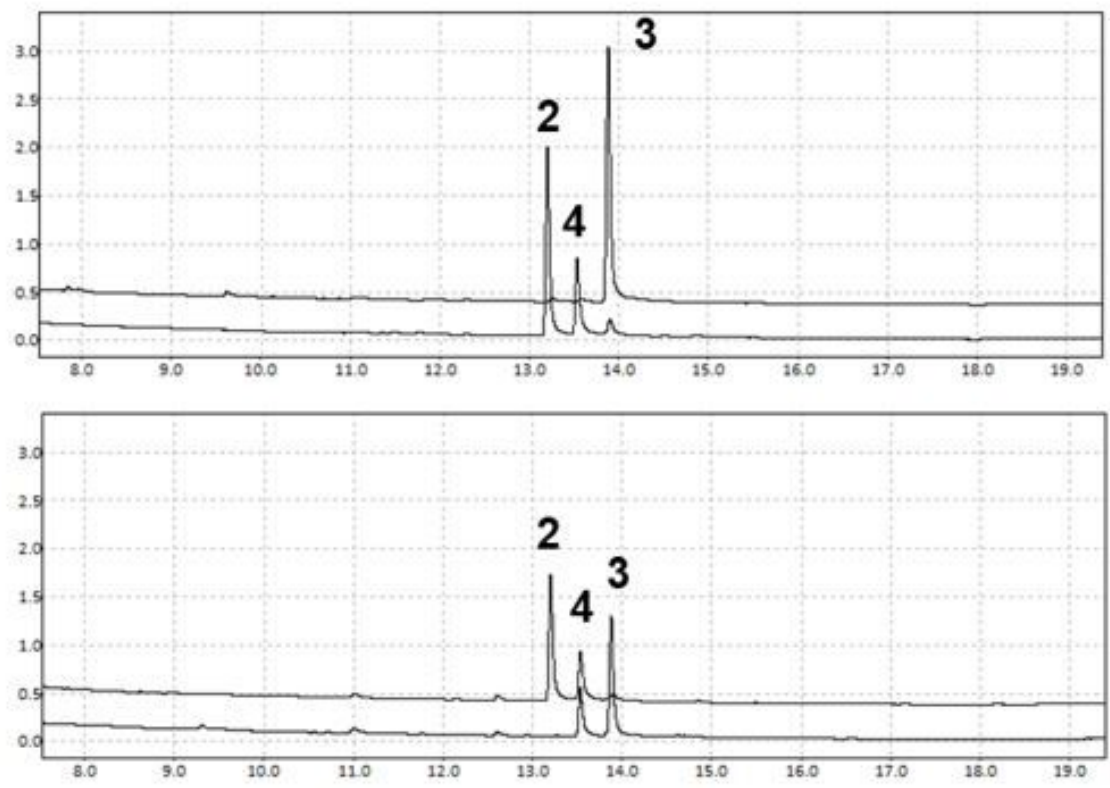

Authentic standards

Ma: BL21(DE3) pCDF-ATR2

Mpa: BL21(DE3) pCDF-CYP71D18-ATR2
Authentic (-)-carvone

Authentic (-)-carveol

$\mathrm{H}: \mathrm{BL} 21$ (DE3) pET

Hc: BL21(DE3) pET-ISPD

\section{Figure 2}

Limonene and carveol conversions for tests of constructed recombinant E. coli strains using a whole-cell biocatalytic system. (A) Reaction with (-)-limonene and cells expressing cytochrome P450 limonene-6hydroxylase gene from spearmint (CYP71D18) and/or cytochrome P450 reductase (CPR) gene from A. thaliana (ATR2) (Mpa and Ma strains; BL21(DE3) pCDF-CYP71D18-ATR2 and BL21(DE3) pCDF-ATR2). Mpa strain specifically converted (-)-limonene to (-)-trans-carveol. (B) Reaction with (-)-carveol and cells expressing carveol dehydrogenase (CDH) gene from peppermint (ISPD) (Hc strain; BL21(DE3) pETISPD). Hc strain specifically converted (-)-trans-carveol to (-)-carvone. Enzymatic activities were 
confirmed by gas chromatography (GC) analysis. Upper and lower panels indicate the authentic standards and test samples; (-)-limonene (1), (-)-carveol $(2,4)$, and (-)-carvone (3). Commercially available (-)-carveol contains (-)-trans-carveol (2), (-)-cis-carveol (4), and trace of (-)-carvone (3).

\section{A}

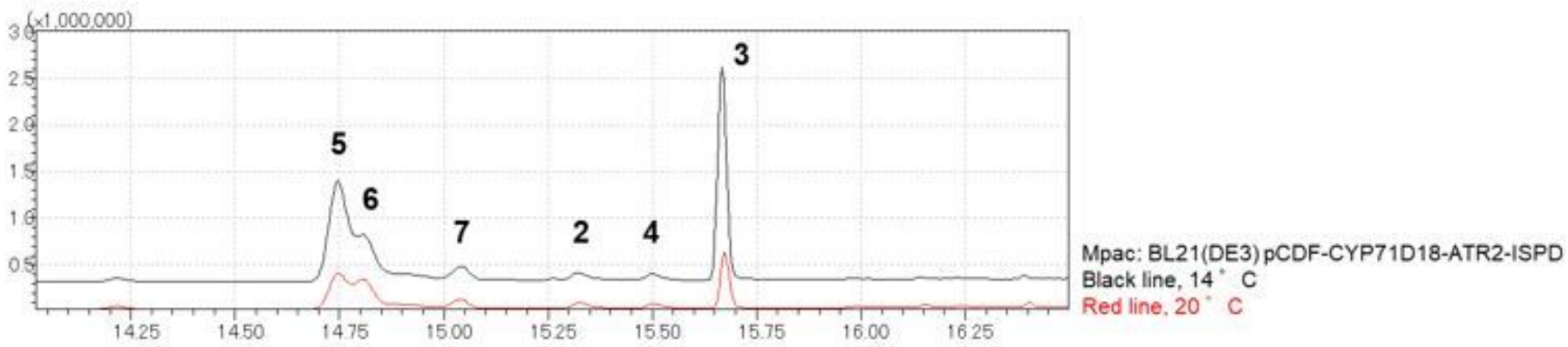

B
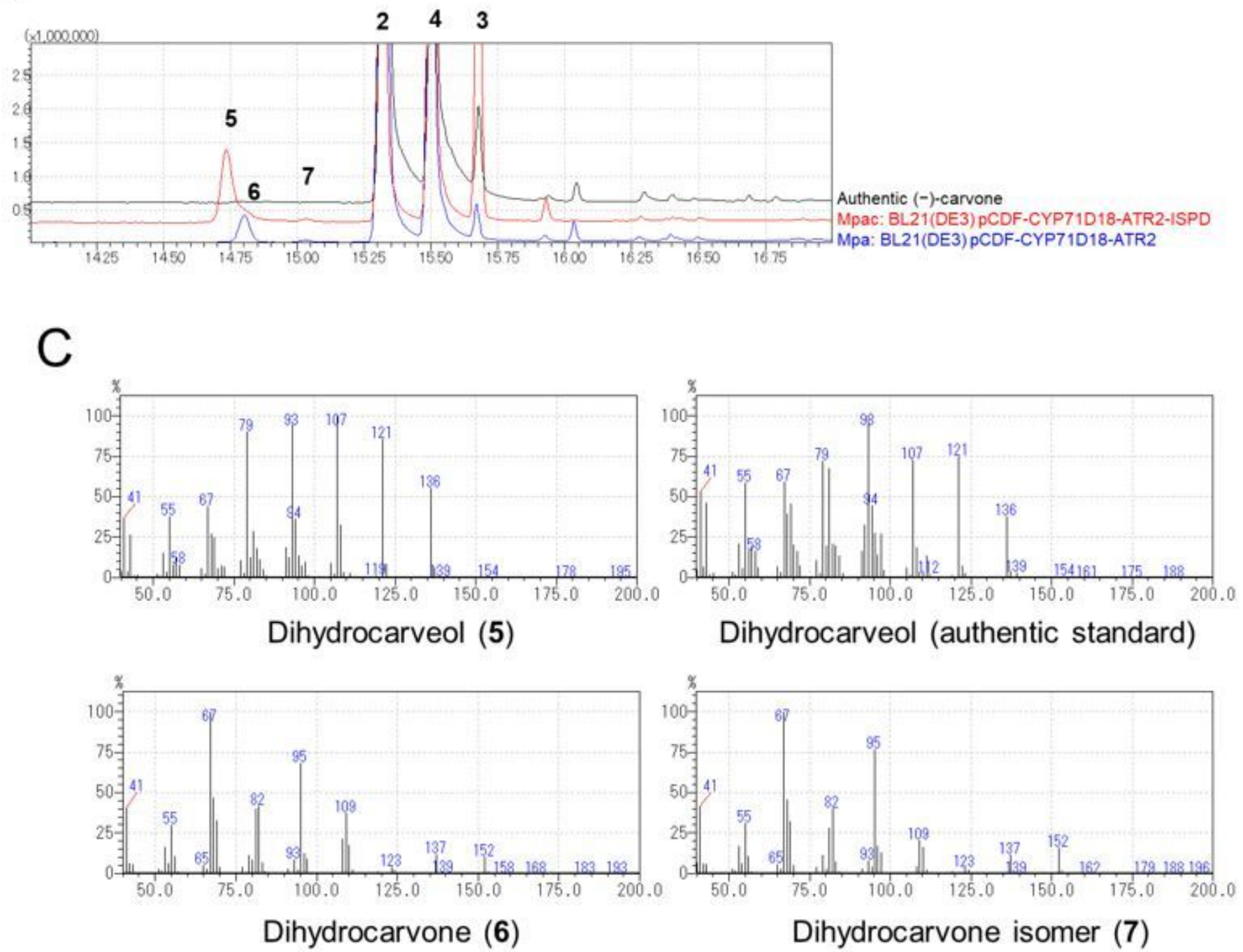

Figure 3

Carvone production from limonene using a recombinant E. coli strain co-expressing P450, CPR and CDH, and identification of by-product compounds. Cytochrome P450 limonene-6-hydroxylase gene from 
spearmint (CYP71D18), cytochrome P450 reductase (CPR) gene from A. thaliana (ATR2), and carveol dehydrogenase (CDR) gene from peppermint (ISPD) were used as P450, CPR, and CDH, respectively. Their enzymatic activities were confirmed by gas chromatography (GC) analysis. (A) Reaction with (-)limonene and cells co-expressing P450, CPR and CDH (Mpac strain; BL21(DE3) pCDF-CYP71D18-ATR2ISPD) under different temperature conditions (black line, $14{ }^{\circ} \mathrm{C}$; and red line, $20^{\circ} \mathrm{C}$ ). Mpac strain converted $(-)$-limonene to $(-)$-carvone but also generated by-products. (B) Reaction with (-)-carveol and cells expressing P450, CPR, and CDH (Mpac strain, red line), and cells expressing P450 and CPR (Mpa strain, blue line), respectively. Mpac strain generated an undetermined by-product, compound (5). Mpa strain generated an undetermined by-product, compound $(6,7)$. Black line indicates authentic $(-)$-carveol standard. Commercially available (-)-carveol contains (-)-trans-carveol (2), (-)-cis-carveol (4), and trace of (-)-carvone (3). (C) Mass spectrometry (MS) fragment pattern of the reaction products with (-)limonene and cells expressing P450, CPR and CDH (Mpac strain), and the authentic standard (dihydrocarveol). Fragment patterns determined by GC-MS analysis indicated that the undetermined byproducts were dihydrocarveol and dihydrocarvone. Numbers indicate the following compound: (-)-transcarveol (2), (-)-carvone (3), (-)-cis-carveol (4), dihydrocarveol (5), dihydrocarvone (6), dihydrocarvone isomer (7).

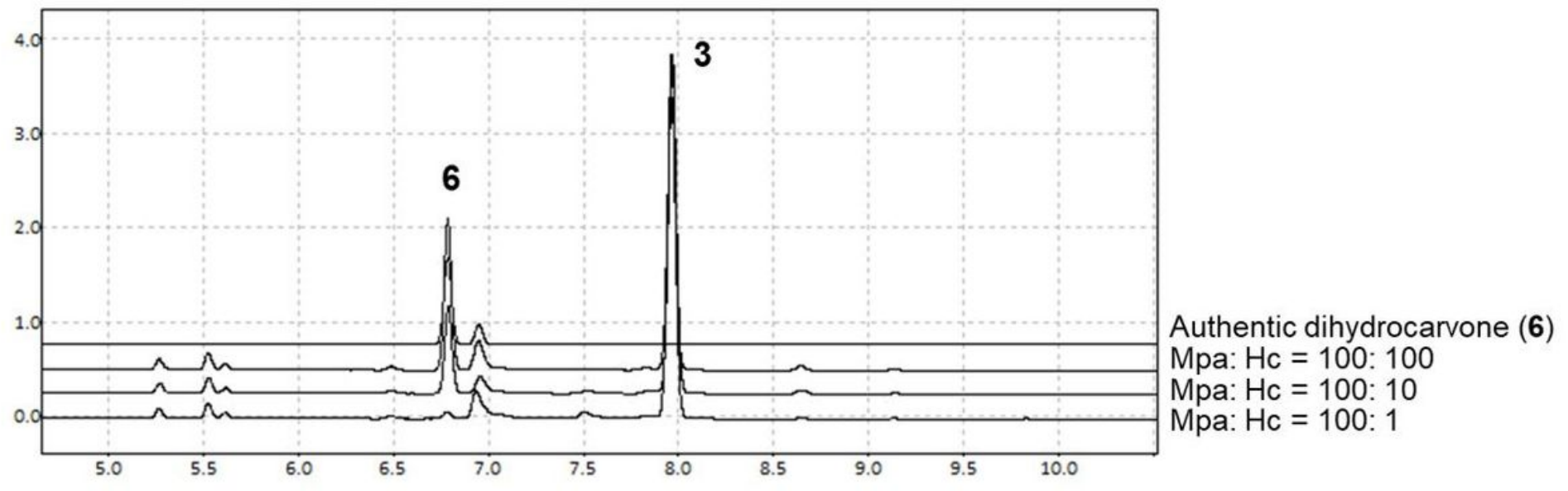

\section{Figure 4}

Optimization of enzyme balance by mixing two strains expressing P450/CPR and CDH enzymes. Strains expressing P450 and CPR (Mpa strain; BL21(DE3) pCDF-CYP71D18-ATR2) or CDH (Hc strain; BL21(DE3) PET-ISPD) were mixed in various ratios to find the optimum balance for converting (-)-limonene to (-)carvone. Varied P450/CDH input results in different (-)-carvone (3) production along with by-product dihydrocarvone (6) production. 
A

QconCAT1

Amino acid sequence

RANPDDPAYDENKVPAFIDETLAAKV

LDPNFADRFGLDASQQIRLHPPFPLI

PRVPIIMIGPGTGLAPFRGGTVAESIG

GRDLESLTAEVDRAVVIADMQPEKVV

DDILVEQGAQREDTVLGGEYPLEKV

EGQVALITGAAR

\section{QconCAT2}

\section{Amino acid sequence}

\section{RVPAFIDETLAAKDLESLTAEVDRANP DDPAYDENKAVVIADMQPEKVVDDILV EQGAQRLHPPFPLIPRVEGQVALITGA ARVLDPNFADRFGLDASQQIREDTVL GGEYPLEKGGTVAESIGGRVPIIMIGP GTGLAPFR}

\section{QconCAT1}

Nucleotide sequence

\begin{abstract}
GGATCCCGTGCGAATCCGGACGACCCGGCGTATGACGAAAACAAAGTTCCG GCGTTTATTGACGAGACCCTGGCGGCGAAGGTTCTGGACCCHAAACNTUGCE GACCGTTTTGGCCTGGATGCGAGCCAGCAAATCCGTCTGCACCCGCCGTTC CCGCTGATCCCGCGTGTGCCGATCATTATGATTGGTCCGGGTACCGGTCTG GCGCCGTTTCGTGGTGGCACCGTGGCGGAGAGCATTGGTGGCCGTGACCTG GAGAGCCTGACCGCGGAAGTTGACCGTGCGGTGGTTATCGCGGATATGCAG CCGGAAAAGGTGGTTGACGATATTCTGGTGGAGCAGGGCGCGCAACGTGAA GATACCGTTCTGGGTGGTGAATACCCGCTGGAAAAGGTGGAAGGTCAAGTG GCGCTGATTACCGGTGCGGCGCGTCTCGAG
\end{abstract}

\section{QconCAT2}

\section{Nucleotide sequence}

GGATCCCGT GTGCCGGCGTTIATTGATGAGACCCTGGCGGCGAAGGACCTG GAGAGCCTGACCGCGGAAGTGGACCGTGCGAACCCGGACGATCCGGCGTAO GATGAGAACAAGGCGGTGGTTATCGCGGACATGCAGCCGGAGAAAGTGGTT GACGATATTCTGGTGGAACAAGGT GCGCAGCGT CTGCACCCGCCGTTCCCG CTGATCCEGCGT GTGGAAGGTCAAGTTGCGCTGATTACCGGTGCGGCGCGT GITCTGGACCCGAACTTCSCGGAT CGTTTTGGCCTGGACGCGAGCCAGCAA ATCCGTGAGGATACCGTGCTGGGT GGCGAGTATCCGCTGGAAAAGGGTGGC ACCGTTGCGGAAAGCATTGGTGGTCGTGTTCCGATTATTATGATTGGTCCG GGCACCGGTCTGGCGCCGTTTCGTCTCGAG

Color representation

Green:ISPD, Blue:LimC, Yellow:CYP71D18, Orange:ATR2,

Gray: CYP102A1 (Not used in this study), Red: BamHI site, Purple: Xhol site, Black: Inserted R

B

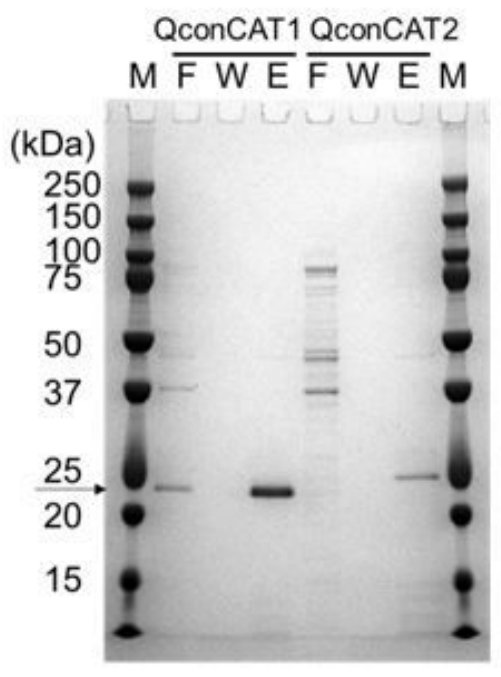

C

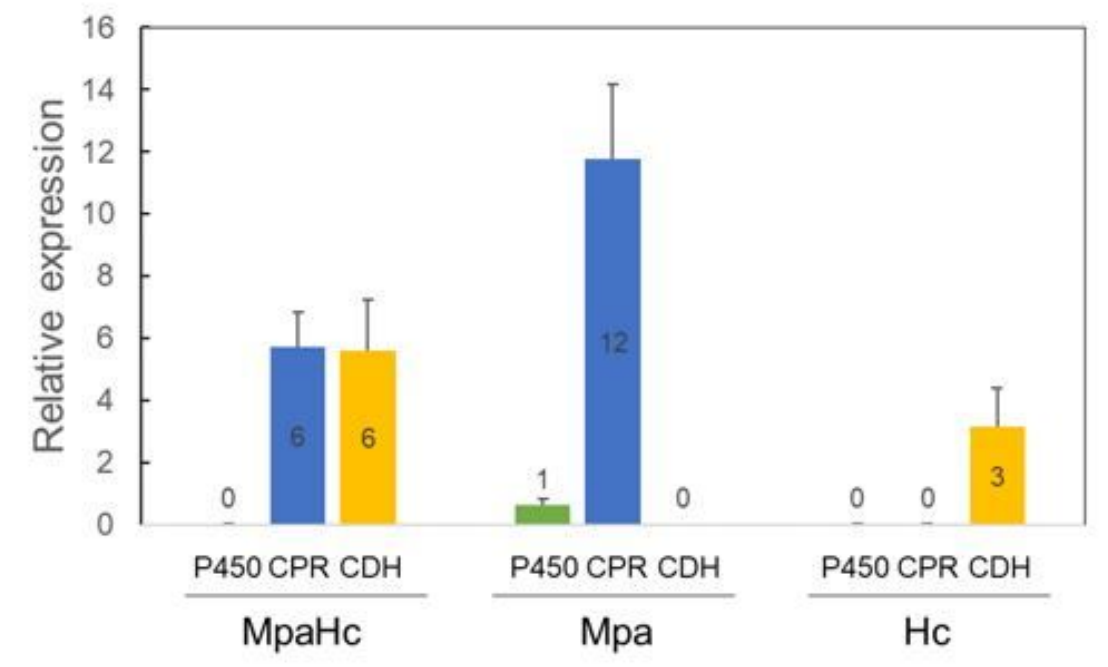

\section{Figure 5}

Enzyme expression level quantification by proteome analysis using QconCAT method. To find the optimum balance for converting limonene to carvone, the semi-quantitative proteome analysis using QconCAT protein was conducted for strains expressing P450, CPR or CDH. (A) QconCAT standard protein design. Two tryptic peptides were chosen based on the preliminary study to represent each protein. The peptide sequences were concatenated in two different orders to make QconCAT1 and QconCAT2. Internal 
BamHI and Xhol sites were substituted with synonymous codons. Codons were optimized for $\mathrm{E}$. coli expression by GenScript. (B) Purification of QconCAT proteins. SDS-PAGE image showed that QconCAT proteins (20 kDa, indicated by an arrow) were correctly expressed and purified. Applied samples per lane were indicated as following; M: molecular mass standard marker, F: flow through, W: wash, E: elution fractions. The positions of the molecular mass standards are indicated. (C) Semi-quantitative proteome analysis using QconCAT method. Relative expression amounts of P450, CPR and CDH in each strain were determined using QconCAT1 protein as a standard. MpaHc strain expressed P450, CPR and CDH (BL21(DE3) pCDF-CYP71D18-ATR2, pET-ISPD). Mpa strain expressed P450 and CPR (BL21(DE3) pCDFCYP71D18-ATR2). Hc strain expressed CDH (BL21(DE3) pET-ISPD). The relative expression amount was shown as an average of three independent clones. Error bars represent standard deviations of $n=3$.

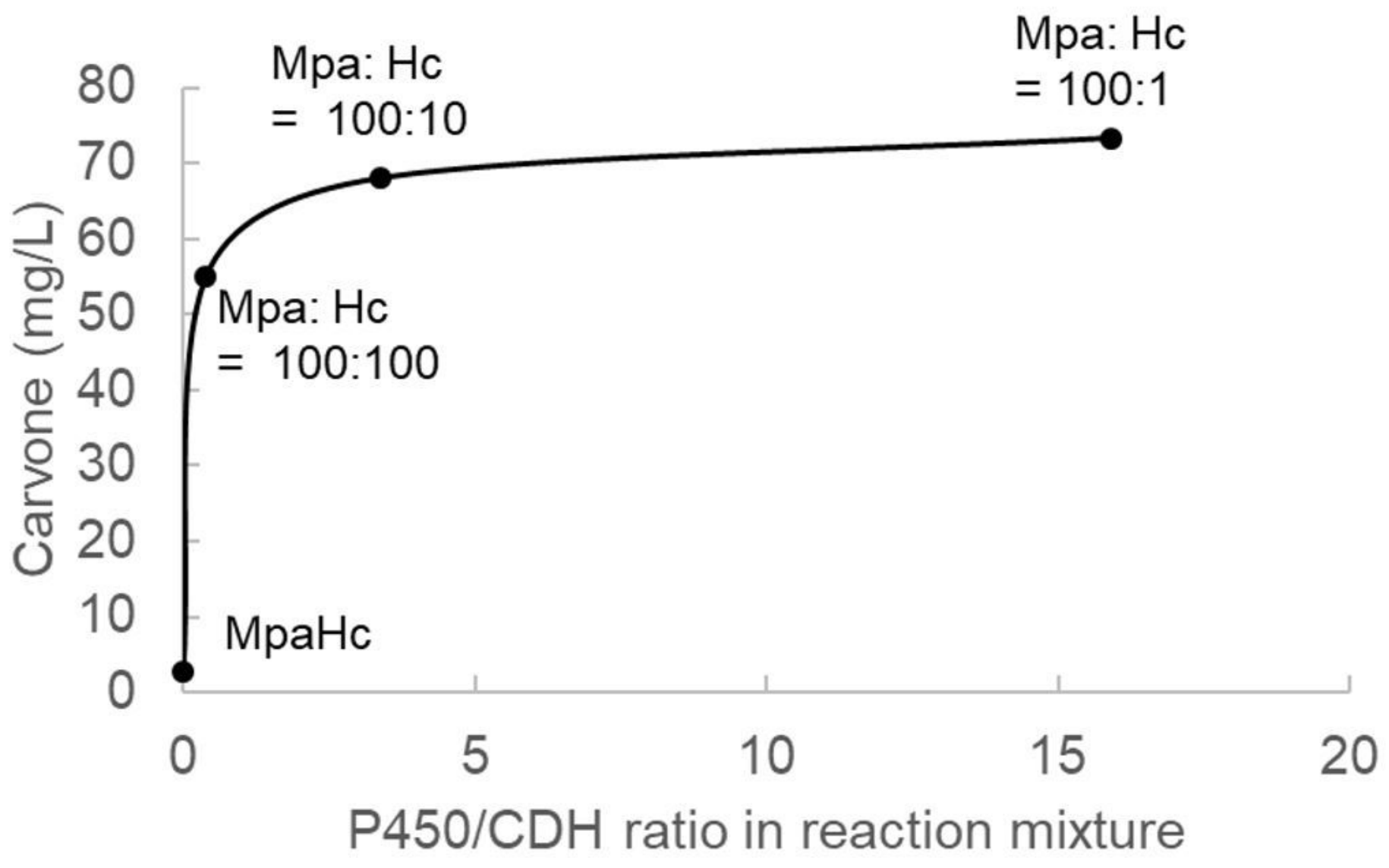

Figure 6

Correlation of $\mathrm{P} 450 / \mathrm{CDH}$ protein ratio and produced carvone amount. $\mathrm{P} 450 / \mathrm{CDH}$ ratio was calculated based on the QconCAT proteome analysis and its correlation between carvone production was shown. Each plot on the graph represents 4 different conditions. From left to right MpaHc (BL21(DE3) pCDFCYP71D18-ATR2, pET-ISPD) showing P450/CDH ratio of 0.004, Mpa (BL21(DE3) pCDF-CYP71D18-ATR2) and $\mathrm{Hc}$ (BL21(DE3) pET-ISPD) mixture (100:100) showing 450/CDH ratio of 0.388, Mpa and Hc mixture (100:10) showing 450/CDH ratio of 3.4, and Mpa and Hc mixture (100:1) showing P450/CDH ratio of 16 respectfully. Mpa and $\mathrm{Hc}$ mixture ratio is based on the OD value of each strain. 
A
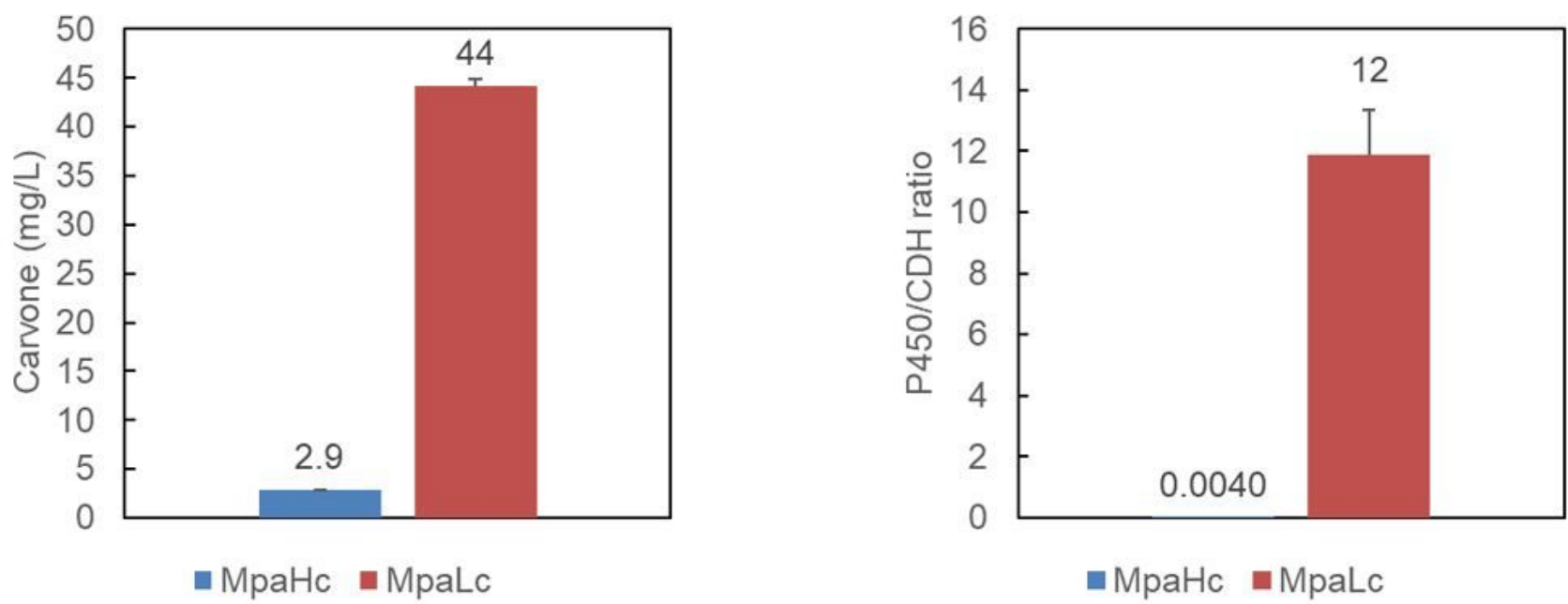

-MpaHc $=\mathrm{MpaLc}$

Figure 7

Carvone conversion by single cell reaction. (A) The novel strain MpaLc (BL21(DE3) pCDF-CYP71D18ATR2, pMW-ISPD) along with previously constructed strain MpaHc (BL21(DE3) pCDF-CYP71D18-ATR2, pET-ISPD) were analyzed using carvone biocatalysis assay with $100 \mathrm{mg} / \mathrm{L}(-)$-limonene as a starting substrate. Error bars represent standard deviations of $n=3$. (B) $P 450 / C D H$ ratio was calculated based on the QconCAT proteome analysis of MpaHc and MpaLc strains. Error bars represent standard deviations of $n=3$.

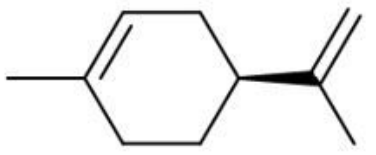

(-)-Limonene (1)
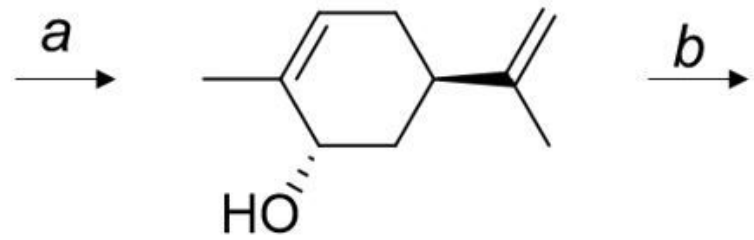

(-)-trans-Carveol(2)
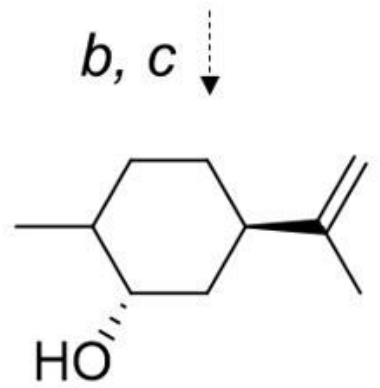

Dihydrocarveol

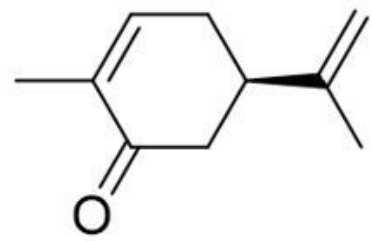

(-)-Carvone

(3)

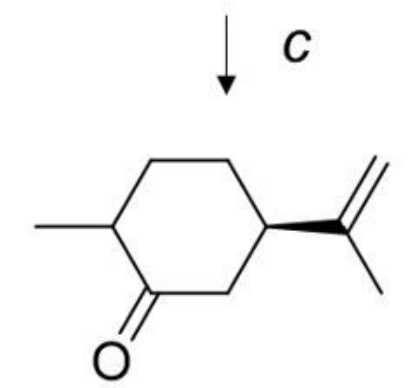

Dihydrocarvone (6)

Dihydrocarvone isomer (7)

Figure 8 
Hypothetical by-product formation pathway. Pathway for the biosynthesis of (-)-carvone from the primary precursor (-)-limonene is shown. The indicated enzymes are (a) cytochrome P450 limonene-6hydroxylase, (b) carveol dehydrogenase, and (c) unknown endogenous enzyme.

\section{Supplementary Files}

This is a list of supplementary files associated with this preprint. Click to download.

- Additionalfile1.docx

- Additionalfile2.docx

- Additionalfile3.docx

- Additionalfile4.xlsx 